\title{
On the occurrence and toxicity of Cylindrospermopsis raciborskii in Poland
}

\author{
Piotr Rzymski ${ }^{1}$, Agnieszka Brygider ${ }^{2}$, Mikołaj Kokociński ${ }^{2}$ \\ ${ }^{1}$ Department of Environmental Medicine, Poznan University of Medical Sciences, Rokietnicka 8, 60-806 Poznań, Poland, \\ e-mail: rzymskipiotr@ump.edu.pl (corresponding author) \\ ${ }^{2}$ Department of Hydrobiology, Adam Mickiewicz University, Umultowska 89, 61-614 Poznań, Poland, \\ e-mail: a_brygider@o2.pl,kok@amu.edu.pl
}

\begin{abstract}
Cylindrospermopsis raciborskii which belongs to the order of Nostocales has continuously been at the centre of interest of various research groups owing to its great ecological plasticity, wide distribution and potential to produce different metabolites known to be harmful for humans and animals. Over recent decades, Polish strains of $C$. raciborskii have also been studied with regard to these issues. The present paper is a brief review of the present state of knowledge respecting the occurrence and toxicity of this species with emphasis on Polish strains, and indicates potential directions for future research.
\end{abstract}

Key words: cyanobacteria; Cylindrospermopsis raciborskii; cyanotoxins; toxicity; Polish lakes

\section{Introduction}

Cylindrospermopsis raciborskii (Woloszynska 1912) Seenayya et Subba Raju (1972) is a freshwater, planktonic filamentous and nitrogen-fixing cyanobacteria belonging to the Nostocales order (Antunes et al. 2015). It is undoubtedly one of the most widely studied nostocaleans for a number of reasons: (i) its near global distribution encompassing Europe, Asia, North and South America, Africa, Australia and New Zealand, and spanning different climate conditions (Rzymski and Poniedziałek 2014); (ii) its potential to produce various metabolites recognized as toxic to humans and animals that, inter alia, include: cylindrospermopsin (CYN), saxitoxins (STXs) and polymethoxy-1-alkenes (PMA) (Ohtani et al. 1992; Jaja-Chimedza et al. 2012; Hoff-Risseti et al. 2013); (iii) the toxicity of certain strains linked to the potential production of hitherto unknown compound(s) (e.g. see Acs et al. 2013; Smutná et al. 2016; Rzymski et al. 2017); (iv) the geographical diversification of toxin production raising questions as to the evolutionary/environmental reasons behind this phenomenon (Gugger et al. 2005; Cirés et al. 2014; Rzymski and Poniedziałek 2014); (v) no scientific consensus as regards the ecological role of produced metabolites, although some hypotheses, e.g. use in al- lelopathic interactions have been put forward (Holland and Kinnear 2013; Rzymski et al. 2014); (vi) phenotypic plasticity in response to key environmental factors such as temperature, light, nutrient availability (Bonilla et al. 2012); (vii) the occurrence of ecotypes differing in environmental tolerance (Chonudomkul et al. 2004; Bonilla et al. 2016); (viii) the potential for future expansion to new environments and an invasive nature owing to reasons given in the three previous points (Padisák and Reynolds 1998; Sinha et al. 2012; Engström-Öst et al. 2015).

C. raciborskii is a potent bloom forming species, usually found in eutrophic lakes regardless of geographical region (Kokociński et al. 2013; Soares et al. 2013), although its occurrence in low-land rivers has also been reported (Karadžić et al. 2013). It can easily be distinguished from other cyanobacteria under a light microscope by means of morphological features. Its trichomes are solitary and usually straight but coil forms are also known to occur. In Polish lakes only straight forms have been so far identified. Cells are cylindrical or barrel shaped, longer than wide, slightly to distinctly constricted at the cross-walls within the trichome. The terminal position of an elongated drop-like shape heterocyst is a characteristic feature of this species. During unfavorable environmental conditions akinetes are 


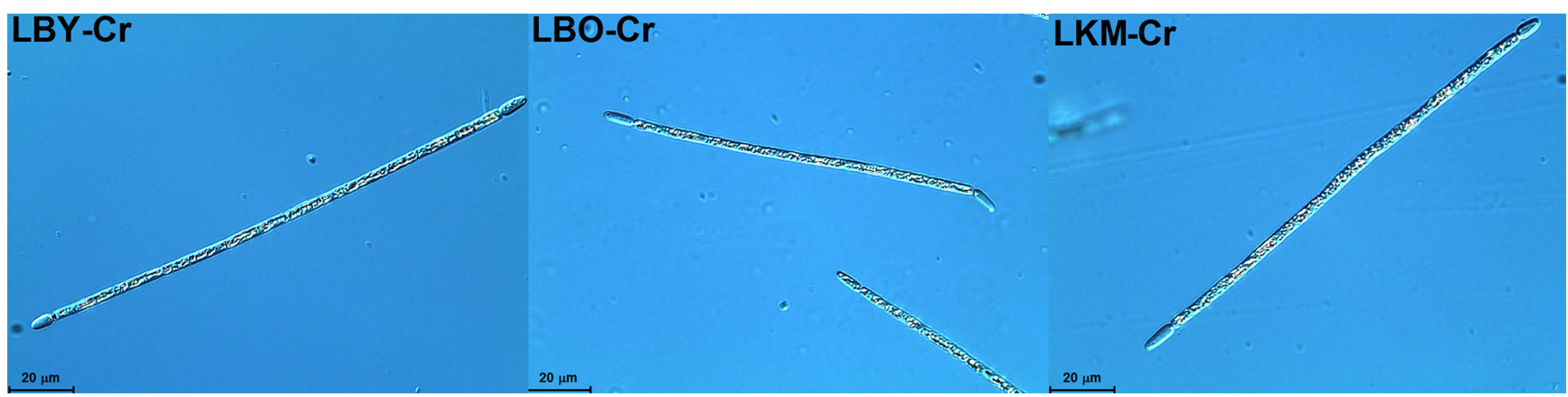

Fig. 1. Morphological features of strains of C. raciborskii isolated from three different freshwater lakes in Western Poland. LBY-Cr: stain

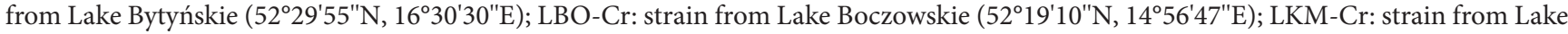
Kierskie Małe $\left(52^{\circ} 29^{\prime} 12^{\prime \prime} \mathrm{N}, 16^{\circ} 47^{\prime} 14^{\prime \prime} \mathrm{E}\right)$

formed. Usually two or three elongated, oval akinetes are located in a row near the ends of trichomes, separated from the heterocyte by a single vegetative cell. The typical morphological forms of $C$. raciborskii which can be observed in Polish lakes are presented in Figure 1.

A comprehensive, multi-approach evaluation of the distribution, frequency of occurrence and potential toxicity of C. raciborskii in different world regions is important not only from an ecological point of view but also in terms of health risk assessment. Over the years, numerous experimental and in-field studies on $C$. raciborskii have been conducted by Australian, Asian, North and South American and European research teams (for reviews see Bonilla et al. 2012; Rzymski and Poniedziałek 2014; Antunes et al. 2015; Burford et al. 2016). Investigations in Poland have contributed to a general understanding of $C$. raciborskii in the temperate zone although a number of unknowns remain that require further attention.

\section{Distribution in Poland}

C. raciborskii was described by Woloszyńska from the island of Jawa (Wołoszyńska 1912) and for many years it was considered as a tropical and subtropical species. In Europe it was first reported in Lake Kastoria in Greece (Skuja 1937). It is postulated that the expansion of $C$. raciborskii toward higher latitudes occurred at the end of the 20th century. The species is widely distributed throughout Europe (Antunes et al. 2015) and recently, it was also reported in the very north-eastern part of Europe in the highly eutrophic Lake Nero in The Yaroslavl Region, Russia (Babanazarova et al. 2015). Therefore, it appears that its northward spread continues. Different theories explaining this phenomenon have been put forward including global warming, phenotypic plasticity or the occurrence of physiologically different ecotypes (Bonilla et al. 2016; Burford et al. 2016).

In Poland C. raciborskii was documented for the first time in the 1970s in the artificially heated Lake
Pątnowskie near Konin in the eastern part of the Wielkopolska region (Burchardt 1977). This lake constitutes part of the cooling system for an electric power plant and receives warm waters discharged throughout the year resulting in steadily increased lake water temperature. Recently, C. raciborskii was reported in the second water body of this cooling system, Lake Licheńskie (Burchardt et al. 2014) which is characterized by the highest water temperature (reaching $30^{\circ} \mathrm{C}$ ) and never forming ice cover (Napiórkowska-Krzebietke 2009). The occurrence of this cyanobacterium has also been reported in several thermally normal lakes of Western Wielkopolska (Stefaniak and Kokociński 2005), including water bodies located in the Wielkopolski National Park (Pełechata and Ławniczak 2013). Its occurrence was also found in the low-land river Samica Stęszewska (Pełechata and Ławniczak 2013). This right tributary of the Warta River flows through the lakes in which C. raciborskii was documented (Kokociński et al. 2013), thus representing a potential route of dispersion.

Large-scale spatial studies have revealed the common occurrence of $C$. raciborskii in the western part of Poland and increasing contribution in total phytoplankton biomass in the investigated lakes (Kokociński and Soininen 2012). Observations of this species have also been reported from the Lubuskie Lakeland in mid-western Poland (Pełechata et al. 2006), Kujawsko-Pomorskie Province in north-central Poland (Kokociński et al. 2013)) and from Lake Rekąty and Lake Piłwąg situated in the region of the Great Mazurian Lakes in northeastern Poland (Jakubowska et al. 2013). However, recent papers concerning cyanobacteria studies from other regions of Poland do not report of the presence of this species (Kobos et al. 2013; Bukowska et al. 2014). In addition, the latest spatial studies in Poland and Lithuania revealed that the occurrence of $C$. raciborskii is limited to the western part of Poland and a single presence in Lithuania (Kokociński et al. 2016). It generally occurs in turbid, shallow, eutrophic lakes with increased concentration of phosphorus and nitrogen (Kokociński and 
Soininen 2012) while its contribution to the total phytoplankton biomass is usually not high, even during cyanobacterial blooms, and maximally does not exceed 30\% (usually being considerably lower) (Kokociński et al. 2013). Moreover, its numerous occurrence is limited to the warmest summer months, although single filaments have also been observed during colder temperatures in late September and October (Brygider and Kokociński 2016). The long term phytoplankton analysis in Poland revealed the ability of $C$. raciborskii to outcompete a native bloom forming cyanobacterial species Planktothrix agardhii (Kokociński et al. 2010). It was also experimentally evidenced that the Polish strain of $C$. raciborskii can outcompete Microcystis aeruginosa even at relatively low initial biomass (Rzymski et al. 2014).

\section{Potential toxicity}

C. raciborskii is a potent toxin producer. This feature is not only geographically-diversified (Rzymski and Poniedziałek et al. 2014) but particular strains from the same region can also vary in this respect (Chonudomkul et al. 2004). Furthermore, particular populations may be constituted of non-toxic and toxic strains cooccurring within the same habitat while toxin-positive strains may also vary in levels of biosynthesized toxin (Willis et al. 2016).

The first toxic compound ever identified (in 1992) for $C$. raciborskii was CYN, a polyketide-derived alkaloid with a central functional guanidino moiety combined with hydroxymethyluracil attached to its tricyclic carbon skeleton (Poniedziałek et al. 2012). Later, other species were also identified as potent CYN-producers. The toxin is actively released by intact cells to the extracellular environment (Preußel et al. 2009), remaining relatively stable over a wide range of $\mathrm{pH}$ and temperature (Chiswell et al. 1999); it can accumulate in the water column and has been found in sediments from approximately 4700 years ago (Waters 2016). CYN has been reported to be produced by $C$. raciborskii strains from Australia and New Zealand (Hawkins et al. 1997; Wood and Stirling 2003), and Asia (Lei et al. 2014). To date no European strain of $C$. raciborskii, including Polish strains, have been identified as either producers of CYN or possessors of genes involved in its biosynthesis (Antal et al. 2011; Kokociński et al. 2013; Rzymski et al. 2017). Other cyanobacterial producers of CYN were, however identified in Europe, e.g. Aphanizomenon gracile in Poland (Kokociński et al. 2013) or Oscillatoria sp. in France (Mazmouz et al. 2010). Although one recent study has reported the alleged production of CYN by C. raciborskii blooming in Lake Aleksandrovac in Serbia, the whole conclusion was not based on any molecular and/or analytical investigation of the isolated strain (Dorđević et al. 2015). Moreover, Svirčev et al. 2016 found that the strain from this reservoir exhibits toxicity in Artemia salina bioassays but does not produce CYN, STX or microcystin (MC).

The second important group of toxins which are known to be produced by C. raciborskii are STXs. However, their production has only been confirmed for strains from South America (Rzymski and Poniedziałek 2014). The presence of STX was reported in a bloom dominated by C. raciborskii in Greece but convincing evidence is insufficient due to a lack of molecular and analytical studies conducted on the isolated strain (Gkelis and Zaoutsos 2014). Nevertheless, other nostocalean cyanobacteria are known to be responsible for STX production (Ballot et al. 2010; Cirés et al. 2014). STXs are neurotoxic alkaloids that block voltage-gated sodium channels in neuronal cells, also implicated in paralytic shellfish poisoning (O'Neill et al. 2016). To date, over 55 analogues that vary in toxicity have been identified including non-sulfated, mono-sulfated, disulfated, decarbamoylated and hydrophobic variants (Wiese et al. 2010).

Interestingly, one strain from Tunisia (Bir M'cherga reservoir) was reported to possess two segments from the $m c y$ gene cluster ( $m c y A$ and $m c y E$ genes) involved in the production of $\mathrm{MC}$, a cyclic peptide hepatotoxin although the concentrations of toxin were below the detection limit (Fathalli et al. 2011). Most recently, a preliminary report on the production of MC by a Greek strain of C. raciborskii has been demonstrated (Panou et al. 2016).

It was also lately found that North American strains of $C$. raciborskii are able to produce lipophilic congeners of PMA which exert toxic and specifically, teratogenic activity in the zebrafish embryo (Jaja-Chimedza et al. 2012; Jaja-Chimedza et al. 2015). To date, no strains from other geographical regions have been screened for the production of PMAs. Such studies are imperative given the fact that a number of European strains of C. raciborskii were found to display in vitro and in vivo toxicity but no known cyanotoxins were identified. For example, extracts from German isolates were toxic to primary rat hepatocytes, human hepatoblastoma and human colon adenocarcinoma cells (Fastner et al. 2003). Exposure of rodents to a French strain of $C$. raciborskii caused liver damage (Bernard et al. 2003). Hepatotoxicity as well as neurotoxic effects (lethargy, piloerection, and difficulty in breathing) were observed in mice exposed to crude extracts of a Portuguese strain (Saker et al. 2003). In turn, extracts of Lake Balaton strains were reported to be toxic in four bioassays: Thamnocephalus platyurus acute lethality test; Daphnia magna acute immobilization assay; D. magna feeding inhibition assay and Danio rerio embryo developmental toxicity assay 


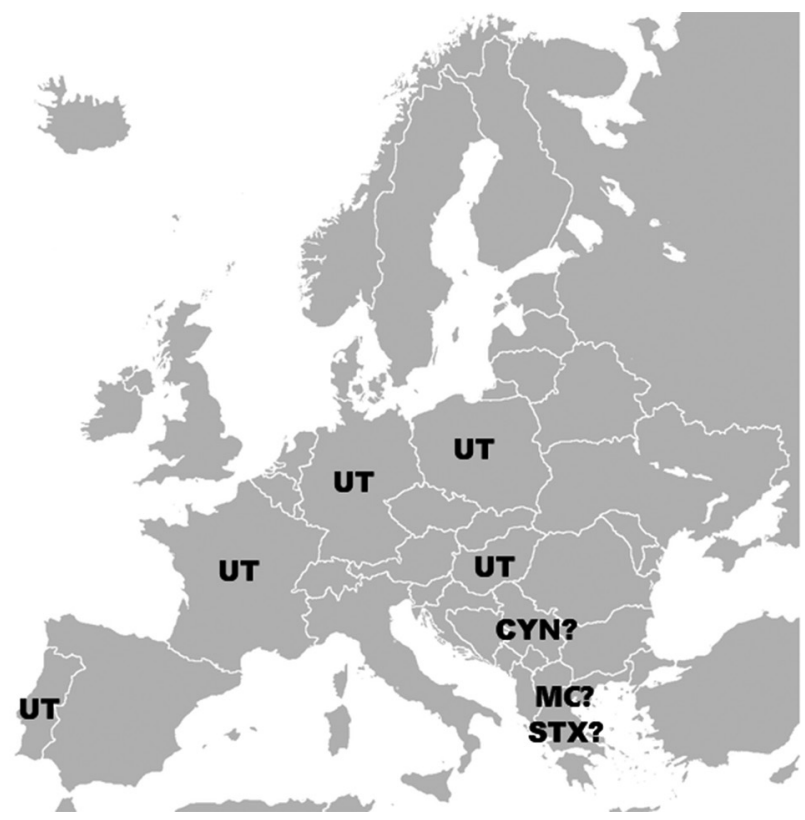

Fig. 2. Potential toxicities identified to date for strains of C. raciborskii occurring in different European locations. CYN - cylindrospermopsin; MC - microcystin; STX - saxitoxin; UT - unknown toxin(s), toxicity confirmed experimentally; ? - uncertain and requiring further confirmation. See text for details

(Acs et al. 2013). Moreover, retinoid-like activity provoking teratogenic effects in frog embryos was recently found for one strain from Lake Balaton (Smutná et al. 2016). Other Hungarian strains were, in turn, shown to evoke neurotoxicity involving inhibition of the acetylcholine responses in Helix pomata (Vehovszky et al. 2015). Toxic effects were also found for Polish strains of C. raciborskii (see "Toxicity of Polish strains" section). The state-of-the-art of the toxic potential of European strains of C. raciborskii is summarized in Figure 2.

\section{Toxicity of Polish strains}

Toxicological studies employing an in vitro experimental model revealed that certain strains of $C$. raciborskii from Western Poland can produce toxic compound(s). Specifically, cell-free extracts obtained from these strains were found to decrease proliferation and induce apoptosis in human T-lymphocytes (Poniedziałek et al. 2015) and cause oxidative stress in human neutrophils, eventually leading to lipid peroxidation and decreased cell survival (Rzymski et al. 2017). Importantly, adverse responses were observed in time as short as $1 \mathrm{~h}$ indicating that the potential risk arising from the produced toxin(s) is rather high (Poniedziałek et al. 2015; Rzymski et al. 2017).

To date, Polish strains have not been found to produce any known toxic metabolites although screening of a relatively wide number of metabolites was conduct- ed (on an analytical and molecular level) and included CYN, STXs, guanidineacetate, anatoxin-a (ANA-A), $\alpha-\gamma$,-diaminobutyric acid (DAB), $\beta-\mathrm{N}$-methylaminoL-alanine (BMAA) and MC (Mankiewicz-Boczek et al. 2012; Kokociński et al. 2013; Rzymski et al. 2017).

In another study, extracts obtained from the Polish strain of $C$. raciborskii induced the production of alkaline phosphatase, a response similar to that observed for CYN (isolated from the Australian strain of C. raciborskii) and it was suggested that it may be involved in allelopathic interactions (Rzymski et al. 2014). However, this strain was not found to contain genes from the $c y r$ cluster, including cyrA which encodes the product associated with the initial reaction, transformation of guanidineacetate substrate, in CYN biosynthesis (Rzymski et al. 2017). Further studies are necessary to identify compounds produced by Polish strains of $C$. raciborskii which are involved in reported toxicity and allelopathic effects.

\section{Conclusions}

C. raciborskii is frequently found in the lakes of western Poland although it does not usually reach high frequency in the phytoplankton community and does not form blooms under current environmental conditions. Similarly to findings from other areas of Europe, Polish strains of this species are able to produce toxic compound(s) although no synthesis of CYN, MC, ANA-A, STX, BMAA and DAB was found. The toxic compounds have yet to be identified.

\section{Acknowledgment}

Piotr Rzymski is supported by the Foundation for Polish Science within the "Start" Program (091.2016).

\section{References}

Acs A., Kovács A.W., Csepregi J.Z., Törö N., Kiss G., Győri J., Vehovszky A., Kováts N., Farkas A., 2013, The ecotoxicological evaluation of Cylindrospermopsis raciborskii from Lake Balaton (Hungary) employing a battery of bioassays and chemical screening, Toxicon 70: 98-106.

Antal O., Karisztl-Gácsi M., Farkas A., Kovács A., Acs A., Töro N., Kiss G., Saker M.L., Gyori J., Bánfalvi G., Vehovszky A., 2011, Screening the toxic potential of Cylindrospermopsis raciborskii strains isolated from Lake Balaton, Hungary, Toxicon 57: 831-840.

Antunes J.T., Leão P.N., Vasconcelos V.M., 2015, Cylindrospermopsis raciborskii: review of the distribution, phylogeography, and ecophysiology of a global invasive species, Front. Microbiol. 6: 473. 
Babanazarova O.V., Sidelev S.I., Fastner J., 2015, Northern expansion of Cylindrospermopsis raciborskii (Nostocales, Cyanoprokaryota) observed in shallow highly eutrophic lake Nero (Russia), Int. J. Algae 17(2): 131-141.

Ballot A., Fastner J., Wiedner C., 2010, Paralytic shellfish poisoning toxin-producing cyanobacterium Aphanizomenon gracile in Northeast Germany, Appl. Environ. Microb. 76(4): 1173-1180.

Bernard C., Harvey M., Briand J.F., Biré R., Krys S., Fontaine J.J., 2003, Toxicological comparison of diverse Cylindrospermopsis raciborskii strains: evidence of liver damage caused by a French $C$ raciborskii strain, Environ. Toxicol. 18(3): 176-186.

Bonilla S., Aubriot L., Soares M.C., González-Piana M., Fabre A., Huszar V.L., Lürling M., Antoniades D., Padisák J., Kruk C.., 2012, What drives the distribution of the bloom-forming cyanobacteria Planktothrix agardhii and Cylindrospermopsis raciborskii?, FEMS Microbiol. Ecol. 79(3): 594-607.

Bonilla S., Gonzáles-Piana M., Soares M. C. S., Huszar V. L. M., Becker V., Somma A., Marinho M. M., Kokociński M., Dokulil M., Antoniades D., Abriot L., 2016, The success of the cyanobacterium Cylindrospermopsis raciborskii in freshwaters is enhanced by the combined effects of light intensity and temperature, J. Limnol. 75(3): 606-617.

Brygider A., Kokociński M., 2016, Cylindrospermopsis raciborskii - a growing ability of tropical cyanobacterium to adapt to conditions in temperate lakes of Western Poland (northern Greater Poland, lake Pniewskie and Kierskie Małe) [Abstract], Abstract book of the 11th International Conference of Young Naturalists "From Biotechnology to Environmental Protection” - Interdisciplinary Meeting of Young Naturalists, Zielona Góra, Poland, 23-26 November.

Bukowska A., Bielczyńska A., Karnkowska A., Chróst R.J., Jasser I., 2014, Molecular (PCR-DGGE) versus morphological approach: analysis of taxonomic composition of potentially toxic cyanobacteria in freshwater lakes, Aquat. Biosyst. 10: 2.

Burchardt L., Hindák F., Komárek J., Lange-Bertalot H., Messyasz B., Pikosz M., Wejnerowski Ł., Jakubas E., Rybak A., Gąbka M., 2014, Spring phytoplankton and periphyton composition: case study from a thermally abnormal lakes in Western Poland, Biodiv. Res. Conserv. 36: 17-24.

Burchardt L., 1977, Changes in phytoplankton composition of Lake Pątnowskie, receiver of heated waste water from sugar factory (1972/73), Ser. Biologia 8: 1-119.

Burford M.A., Beardall J., Willis A., Orr P.Y., Magalhaes V.F., Rangel L.M., Azevedo S.M.F.O.E., Neilan B.A., 2016, Understanding the winning strategies used by the bloomforming cyanobacterium Cylindrospermopsis raciborskii, Harmful Algae 54: 44-53.

Chiswell R.K., Shaw G.R., Eaglesham G., Smith M.J., Norris R.L., Seawright A.A., Moore M.R., 1999, Stability of cylindrospermopsin the toxin from the cyanobacterium
Cylindrospermopsis raciborskii: effect of $\mathrm{pH}$ temperature and sunlight on decomposition, Environ. Toxicol. 14(1): 155-161.

Chonudomkul D., Yongmanitchai W., Theeragool G., Kawachi M., Kasai F., Kaya K., Watanabe M.M., 2004, Morphology, genetic diversity, temperature tolerance and toxicity of Cylindrospermopsis raciborskii (Nostocales, Cyanobacteria) strains from Thailand and Japan, FEMS Microbiol. Ecol. 48(3): 345-355.

Cirés S., Wörmer L., Ballot A., Agha R., Wiedner C., Velázquez D., Casero M.C., Quesada A., 2014, Phylogeography of cylindrospermopsin and paralytic shellfish toxin-producing nostocales cyanobacteria from mediterranean europe (Spain), Appl. Environ. Microbiol. 80(4): 1359-7130.

Dorđević N., Simić S.B., Ciric A.R., 2015, First identification of the cylindrospermopsin (CYN) producting by cyanobacterium Cylindrospermopsis raciborskii (Woloszynska) Seenayya \& Subba Raju in Serbia, Fresenius Environ. Bull. 24(11a): 3736-3742.

Engström-Öst J., Rasic I.S., Brutemark A., Rancken R., Simić G.S., Laugen A.T., 2015, Can Cylindrospermopsis raciborskii invade the Baltic Sea?, Environ. Rev. 23(2): 161-169.

Fathalli A., Jenhani A.B., Moreira C., Azevedo J., Welker M., Romdhane M., Antunes A., Vasconcelos V., 2011, Genetic variability of the invasive cyanobacteria Cylindrospermopsis raciborskii from Bir M'cherga reservoir (Tunisia), Arch. Microbiol. 193(8): 595-604.

Fastner J., Heinze R., Humpage A.R., Mischke U., Eaglesham G.K., Chorus I., 2003, Cylindrospermopsin occurrence in two German lakes and preliminary assessment of toxicity and toxin production of Cylindrospermopsis raciborskii (Cyanobacteria) isolates, Toxicon 42: 313-321.

Gkelis S., Zaoutsos N., 2014, Cyanotoxin occurrence and potentially toxin producing cyanobacteria in freshwaters of Greece: a multi-disciplinary approach, Toxicon 78: 1-9.

Gugger M., Molica R., Le Berre B., Dufour P., Bernard C., Humbert J.-F., 2005, Genetic diversity of Cylindrospermopsis strains (Cyanobacteria) isolated from four continents, Appl. Environ. Microbiol. 71(2): 1097-1100.

Hawkins P.R., Chandrasena N.R., Jones G.J., Humpage A.R., Falconer I.R., 1997, Isolation and toxicity of Cylindrospermopsis raciborskii from an ornamental lake, Toxicon 35 : 341-346.

Hoff-Risseti C., Dorr F.A., Schaker P.D.C., Pinto E., Werner V.R., Fiore M.F., 2013, Cylindrospermopsin and saxitoxin synthetase genes in Cylindrospermopsis raciborskii strains from Brazilian freshwater, PLOS ONE 8(8): e74238.

Holland A., Kinnear S., 2013. Interpreting the possible ecological role(s) of cyanotoxins: compounds for competitive advantage and/or physiological aide?, Mar. Drugs 11(7): 2239-2258.

Jaja-Chimedza A., Gantar M., Gibbs P.D., Schmale M.C., Berry J.P., 2012, Polymethoxy-1-alkenes from Aphanizomenon ovalisporum inhibit vertebrate development in 
the zebrafish (Danio rerio) embryo model, Mar. Drugs 10(10): 2322-2336.

Jaja-Chimedza A., Saez C., Sanchez K., Gantar M., Berry J.P., 2015, Identification of teratogenic polymethoxy-1-alkenes from Cylindrospermopsis raciborskii, and taxonomically diverse freshwater cyanobacteria and green algae, Harmful Algae 49: 156-161.

Jakubowska N., Zagajewski P., Gołdyn R., 2013, Water blooms and cyanobacterial toxins in lakes, Pol. J. Environ. Stud. 22(4): 1077-1082.

Karadžić V., Simić G.S., Natić D., Ržaničanin A., Ćirić M., Gačić Z., 2013, Changes in the phytoplankton community and dominance of Cylindrospermopsis raciborskii (Wolosz.) Subba Raju in a temperate lowland river (Ponjavica, Serbia), Hydrobiologia 711: 43-60.

Kobos J., Błaszczyk A., Hohlfeld N., Toruńska-Sitarz A., Krakowiak A., Hebel A., Sutryk K., Grabowska M., Toporowska M., Kokociński M., Messyasz B., Rybak A., Napiórkowska-Krzebietke A., Nawrocka L., Pełechata A., Budzyńska A., Zagajewski P., Mazur-Marzec H., 2013, Cyanobacteria and cyanotoxins in Polish freshwater bodies, Oceanol. Hydrobiol. Stud. 42(4): 358-378.

Kokociński M., Stefaniak K ., Mankiewicz-Boczek J., Izydorczyk K., Soininen J., 2010, The ecology of the invasive cyanobacterium Cylindrospermopsis raciborskiii (Nostocales, Cyanophyta) in two hypereutrophic lakes dominated by Planktothrix agardhii (Oscillatoriales, Cyanophyta), Eur. J. Phycol. 45(4): 365-374.

Kokocinski M., Soininen J., 2012, Environmental factors related to the occurrence of Cylindrospermopsis raciborskii (Nostocales, Cyanophyta) at the north-eastern limit of its geographical range, Eur. J. Phycol. 47(1): 12-21.

Kokociński M., Mankiewicz-Boczek J., Jurczak T., Spoof L., Meriluoto J., Rejmonczyk E., Hautala H., Vehniäinen M., Pawełczyk J., Soininen J., 2013, Aphanizomenon gracile (Nostocales), a cylindrospermopsin-producing cyanobacterium in Polish lakes, Environ. Sci. Pollut. Res. Int. 20(8): 5243-5264.

Kokociński M., Gągała I., Jassser I., Kobos J., Koreiviene J., Soininen J., Szczurowska A., Dziga D., Mankiewicz-Boczek J., 2016, Which environmental factors drive the distribution of potentially toxic Cylindrospermopsis raciborskii in Central-Eastern Europe? [Abstract], Abstract book of the 10th International Conference on Toxic Cyanobacteria, 23-28 October 2016, Wuhan (China): 26.

Lei L., Peng L., Huang X., Han B.P., 2014, Occurrence and dominance of Cylindrospermopsis raciborskii and dissolved cylindrospermopsin in urban reservoirs used for drinking water supply, South China, Environ. Monit. Assess. 186(5): 3079-3090.

Mankiewicz-Boczek J, Kokociński M, Gagała I, Pawełczyk J, Jurczak T, Dziadek J., 2012, Preliminary molecular identification of cylindrospermopsin-producing Cyanobacteria in two Polish lakes (Central Europe), FEMS Microbiol. Lett. 326(2): 173-179.
Mazmouz R., Chapuis-Hugon F., Mann S., Pichon V., Mejean A., Ploux O., 2010, Biosynthesis of cylindrospermopsin and 7-epicylindrospermopsin in Oscillatoria sp. strain PCC 6506: identification of the cyr gene cluster and toxin analysis, Appl. Environ. Microbiol. 76(15): 4943-4949.

Napiórkowska-Krzebietke A., 2009, Diversity and dynamics of phytoplankton in Lake Licheńskie and Lake Ślesińskie in 2004-2005, Arch. Pol. Fish. 17(4): 253-265.

Ohtani I., Moore R.E., Runnegar M.T.C., 1992, Cylindrospermopsin: a potent hepatotoxin from the blue-green alga Cylindrospermopsis raciborskii, J. Am. Chem. Soc. 114(20): 7941-7942.

O'Neill K., Musgrave I.F., Humpage A., 2016, Low dose extended exposure to saxitoxin and its potential neurodevelopmental effects: A review, Environ. Toxicol. Pharmacol. 48: 7-16.

Panou M., Zervou S., Christophoridis C., Manolidi K., Triantis T., Kaloudis T., Hiskia A., Gkelis S., 2016, First report of a microcystin-producing Cylindrospermopsis raciborskii strain isolated from Greece [Abstract], Abstract book of the 10th International Conference on Toxic Cyanobacteria, 23-28 October 2016, Wuhan (China): 57.

Padisák J., Reynolds C.S., 1998, Selection of phytoplankton associations in Lake Balaton, Hungary, in response to eutrophication and restoration measures, with special reference to the cyanoprokaryotes, Hydrobiologia 384: 41-53.

Pełechata A., Ławniczak A.E., 2013, New localities of Cylindrospermopsis raciborskii and Anabaenopsis elenkinii within the Wielkopolska National Park, Western Poland [Abstract], Abstract book of the 32nd International Conference of Polish Phycologists "Do thermophilic species invasion threaten us?”, 20-23 May, Konin-Mikorzyn (Poland): 116-117.

Pełechata A., Pełechaty M., Pukacz A., 2006, Cyanoprokaryota of shallow lakes of Lubuskie Lakeland (mid-western Poland), Oceanol. Hydrobiol. Stud. 35(1): 3-14.

Poniedziałek B., Rzymski P., Kokociński M., 2012, Cylindrospermopsin: water-linked potential threat to human health in Europe, Environ. Toxicol. Pharmacol. 34(3): 651-660.

Poniedziałek B., Rzymski P., Kokociński M., Karczewski J., 2015, Toxic potencies of metabolite(s) of non-cylindrospermopsin producing Cylindrospermopsis raciborskii isolated from temperate zone in human white cells, Chemosphere 120: 608-614.

Preußel K., Wessel G., Fastner J., Chorus I., 2009, Response of cylindrospermopsin production and release in Aphanizomenon flos-aquae (Cyanobacteria) to varying light and temperature conditions, Harmful Algae 8(5): 645-650.

Rzymski P., Poniedziałek B., 2014, In search of environmental role of cylindrospermopsin: a review on global distribution and ecology of its producers, Water Res. 66: 320-327.

Rzymski P., Poniedziałek B., Kokociński M., Jurczak T., Lipski D., Wiktorowicz K., 2014, Interspecific allelopathy in cyanobacteria: cylindrospermopsin and Cylindrosper- 
mopsis raciborskii effect on the growth and metabolism of Microcystis aeruginosa, Harmful Algae 35: 1-8.

Rzymski P., Poniedziałek B., Mankiewicz-Boczek J., Faassen E.J., Jurczak T., Gągała-Borowska I., Ballot A., Lürling M., Kokociński M., 2017, Polyphasic toxicological screening of Cylindrospermopsis raciborskii and Aphanizomenon gracile isolated in Poland, Algal Res. 24: 72-80.

Saker M.L., Nogueira I.C., Vasconcelos V.M., Neilan B.A., Eaglesham G.K., Pereira P., 2003, First report and toxicological assessment of the cyanobacterium Cylindrospermopsis raciborskii from Portuguese freshwaters, Ecotoxicol. Environ. Saf. 55(2): 243-250.

Sinha R, Pearson LA, Davis TW, Burford MA, Orr PT, Neilan BA., 2012, Increased incidence of Cylindrospermopsis raciborskii in temperate zones--is climate change responsible?, Water Res. 46(5): 1408-1419.

Skuja H., 1937, Süßwasseralgen aus Griechenland und Kleinasien, Hedwigia 77: 15-73.

Smutná M., Priebojová J., Večerková J., Hilscherová K., 2016, Retinoid-like compounds produced by phytoplankton affect embryonic development of Xenopus laevis, Ecotoxicol. Environ. Saf. 138: 32-38.

Soares M.C.S., Huszar V.L.M., Miranda M.N., Mello M.M., Roland F., Lürling M., 2013, Cyanobacterial dominance in Brazil: distribution and environmental preferences, Hydrobiologia 717: 1-12.
Stefaniak K. Kokociński M., 2005, Occurrence of invasive cyanobacteria species in polimictic lakes of the Wielkopolska region (Western Poland), Oceanol. Hydrobiol. Stud.34 (Suppl. 3): 137-148.

Svirčev Z., Obradović V., Codd G.A., Marjanović P., Spoof L., Drobac D., Tokodi N., Petković A., Nenin T., Simeunović J., Važić T., Meriluoto J., 2016, Massive fish mortality and Cylindrospermopsis raciborskii bloom in Aleksandrovac Lake, Ecotoxicology 25(7): 1353-1363.

Vehovszky Á., Kovács A.W., Farkas A., Győri J., Szabó H., Vasas G., 2015, Pharmacological studies confirm neurotoxic metabolite(s) produced by the bloom-forming $\mathrm{Cyl}$ indrospermopsis raciborskii in Hungary, Environ. Toxicol. 30(5): 501-512.

Waters M.N., 2016, A 4700-year history of cyanobacteria toxin production in a shallow subtropical lake, Ecosystems 19(3): 426-436.

Wiese M., D’Agostino P.M., Mihali T.K., Moffitt M., Neilan B.A., 2010, Neurotoxic alkaloids: Saxitoxin and its analogs, Mar. Drugs 8(7): 2185-2211.

Woloszynska J., 1912, Das Phytoplankton einiger Javanian Seen mit Berücksichtigung des Sawa-Planktons, Bull. Int. Acad. Sci. Cracoviae Ser. B 6: 649-709.

Wood S.A., Stirling D.J., 2003, First identification of the cylindrospermopsin-producing cyanobacterium Cylindrospermopsis raciborskii in New Zealand, New Zeal. J. Mar. Fresh. Res. 37: 821-828. 